\title{
Study of antibiotics and symbiotic effects on sperm quality using
}

\section{the CASA system}

\author{
A. El B. Bouchicha, A. Kalem, N. Mimoune*, S. Djouadi, D. Khelef \\ and R. Kaidi
}

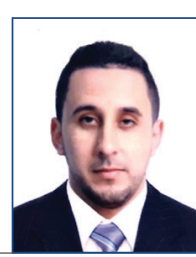

\begin{abstract}
The objective of the current work was to study in vitro sperm quality after antibiotics and symbiotic administration and to evaluate treatment administered before insemination with the aim of reducing artificial insemination failures in goats. This experimental study was carried out at the Animal Reproduction Biotechnology Laboratory (Blida, Algeria). Semen analysis was performed using the Computer-assisted sperm analysis system. In the first experimental approach, we used the antibiotics most commonly administered in the veterinary field for the treatment of subclinical endometritis. A total of eight antibiotics were studied. Each antibiotic tested was coincubated with frozen goat semen brought from the Centre for Artificial Insemination and Genetic Improvement. For the second experimental approach, we incubated semen with a symbiotic (Symbiovéba). Finally, we selected two antibiotics among those used, namely colistin and cotrimoxazole, and these
\end{abstract}

were co-incubated with the symbiotic and the semen, to examine possible combinations of antibiotics with symbiotics in the treatment and prevention of uterine infections (broad spectrum synergistic activity). Antibiotics have been shown to have a detrimental effect on the sperm cell, by decreasing sperm motility. The average value calculated on all antibiotics was $18 \%$ (as opposed to initial motility of $78 \%$ in the control group), with an alteration of the linear speed that would have a negative impact on fertilization. On the other hand, symbiotics had a beneficial effect on spermatozoa motility and vitality. The combination of the symbiotic and colistin proved to be very promising. In conclusion, the use of symbiotics in the treatment of subclinical endometriosis at the time of goat insemination is beneficial, and requires greater attention in future research.

Key words: sperm; antibiotic; symbiotic; CASA; semen; subclinical endometritis

\footnotetext{
Ahmed El Bachir BOUCHICHA, Institute of Sciences and technology, Tissemsilt University, Laboratory of Biotechnologies related to animal reproduction (LBRA), Institute of Veterinary Sciences, Saad Dahleb University, Blida, Algeria; Ammar KALEM, Laboratory of Biotechnologies related to animal reproduction (LBRA), Institute of Veterinary Sciences, Saad Dahleb University, Blida, Algeria; Nora MIMOUNE*, (Corresponding author, e-mail: nora.mimoune@gmail.com), Laboratory of Biorechnologies related to animal reproduction (LBRA), Institute of Veterinary Sciences, Saad Dahleb University, Blida, Algeria, National High School of Veterinary Medicine, Animal Health and Productions Laboratory, El-Alia, Algiers, Algeria; Sohaib DJOUADI, Faculty of Nature \& Life Sciences, Farm Animal Reproduction Laboratory, University of Tiaret, Algeria; Djamel KHELEF, National High School of Veterinary Medicine, Animal Health and Productions Laboratory, El-Alia, Algiers, Algeria; Rachid KAIDI, Laboratory of Biorechnologies related to animal reproduction (LBRA), Institute of Veterinary Sciences, Saad Dahleb University, Blida, Algeria
} 


\section{Introduction}

Uterine infections including subclinical endometritis (SCE) have a major economic impact due to their impacts on reproductive performances (Ahmadi et al., 2006; Đuričić et al., 2013; Oruc et al., 2015; Szenci et al., 2018; Asadpour et al., 2020). Fortunately, treatments are available to improve fertility. The preferred choice of the therapy and administration route differ among veterinarians. Therapy is primarily based on local application of antibiotic preparations, and the selection of antibiotics should be based on the determination of antibiotic resistance. Furthermore, antibiotic preparations have different absorption properties and induce multiple interactions within the uterus (Đuričić et al., 2015; Samardžija et al., 2017).

In order to reduce the performance gaps attributable to artificial insemination (AI) failures, for animals with SCE, some authors recommend an antibioticbased treatment shortly before the act of insemination (Đuričić et al., 2014). In particular, antibiotics have attracted the attention of scientists for their toxic potential on sperm quality. Indeed, invitro studies have revealed the presence of a significant alteration in sperm mobility parameters (Aral, 2008). Furthermore, spermatozoa are sensitive to oxidative stress caused by polynuclear cells and antibiotics due to their structure rich in polyunsaturated fatty acids (Žura Žaja et al., 2016a,b, 2019a,b).

Our objective was to test alternatives to antibiotics for the treatment of genital infections at the time of natural mating or AI. Particularly, we tested in vitro antibiotics and symbiotic effects on sperm motility and vitality of buck semen.

\section{Material and methods}

The study was carried out at the Animal Reproduction Biotechnology
Laboratory of the Veterinary Institute (Saad Dahleb University, Blida 1, Algeria) during the period from June to October 2019.

\section{Semen}

Frozen semen straws from alpine bucks were collected from the National Centre of Artificial Insemination and Genetic Improvement (CNIAAG), Baba Ali, Algiers, Algeria. The volume of each straw was $0.25 \mathrm{~mL}$.

\section{Antibiotics}

In this study, eight antibiotics were tested. They were selected based on the frequency of their use for uterine infection therapy, in particular in the case of SCE: tetracyclines, erythromycin, sulfamethoxazole, gentamycin, colistin, ciprofloxacin, amoxicillin + clavulanic acid, rifampicin.

Table 1. Antibiotics tested with an antibiogram

\begin{tabular}{|c|c|}
\hline Antibiotics & Abbreviation \\
\hline Tetracycline & TE \\
\hline Ciprofloxacin & Cip \\
\hline Erythromycin & E \\
\hline Rifamycin & RD \\
\hline Gentamycin & GN \\
\hline Co-trimoxazole & CoT (SMX) \\
\hline Colistin & CT \\
\hline Amoxicillin + clavulanic & AMC \\
\hline acid & \\
\hline
\end{tabular}

\section{Symbiotic}

The product used in this study is a purely biological additive for veterinary use; SYMBIOVEBA ${ }^{\circ}$ (MARCOPOLO Environmental Group) consists of medicinal plants (Taraxacum officinalis, Zingiber officinalis), probiotics (Lactobacillus and Saccharomycess cervicie), enzymes, and plant extracts. 


\section{CASA system}

This system comprises a microscope linked to a digital camera, the whole is associated with a computer equipped with a software for computer analysis of sperm parameters (Sperm class Analyzer; SCA Version 5.4, microptic SL, Spain). This system performs an automatic analysis of videos of moving spermatozoa to generate objective values of the following mobility parameters: curvilinear velocity (VCL), the average path velocity (VAP), linear speed or VSL (Straight-Line Velocity), ALH (Amplitude of Lateral Head displacement), beat cross frequency $(\mathrm{BCF})$.

\section{Experimental design}

Manipulations were carried out under aseptic conditions to avoid any microbial contamination that could alter the results.

\section{Preparation of solutions}

\section{First part}

\section{Control preparation protocol}

In an Eppendorf flask with $1 \mathrm{~mL} 0.9 \%$ $\mathrm{NaCl}$ (saline solution), we added 0.5 $\mathrm{ml}$ frozen semen. Alternatively, to save straws, we added $0.25 \mathrm{~mL}$ semen to 0.5 $\mathrm{mL} 0.9 \% \mathrm{NaCl}$. The flask was placed in a water bath at $37^{\circ} \mathrm{C}$ to avoid thermal shocks for the sperm. The control made it possible to estimate the impact of antibiotics on spermatic capacity.

\section{Antibiotic + semen solution preparation protocol}

In an Eppendorf flask with $1 \mathrm{~mL}$ saline solution, we added $0.5 \mathrm{ml}$ semen, using two straws each with $0.25 \mathrm{~mL}$, and an antibiotic disc (one antibiotic disc for 1 $\mathrm{ml}$ saline solution to retain the minimum inhibitory concentration (MIC)).

\section{Preparation of samples for analysis}

For sperm motility: a few drops of diluted semen (controls) using $10 \mu \mathrm{L}, 100$ $\mu \mathrm{L}$ micropipette were applied to a slide and a coverslip added for analysis on the CASA computer.

For sperm vitality: $10 \mu \mathrm{L}$ diluted semen $+10 \mu \mathrm{L}$ eosins and $20 \mu \mathrm{L}$ nigrosine were prepared on a slide, and left for 3 to 5 minutes before spreading out and leaving to dry. Finally, slides were analysed on a CASA computer.

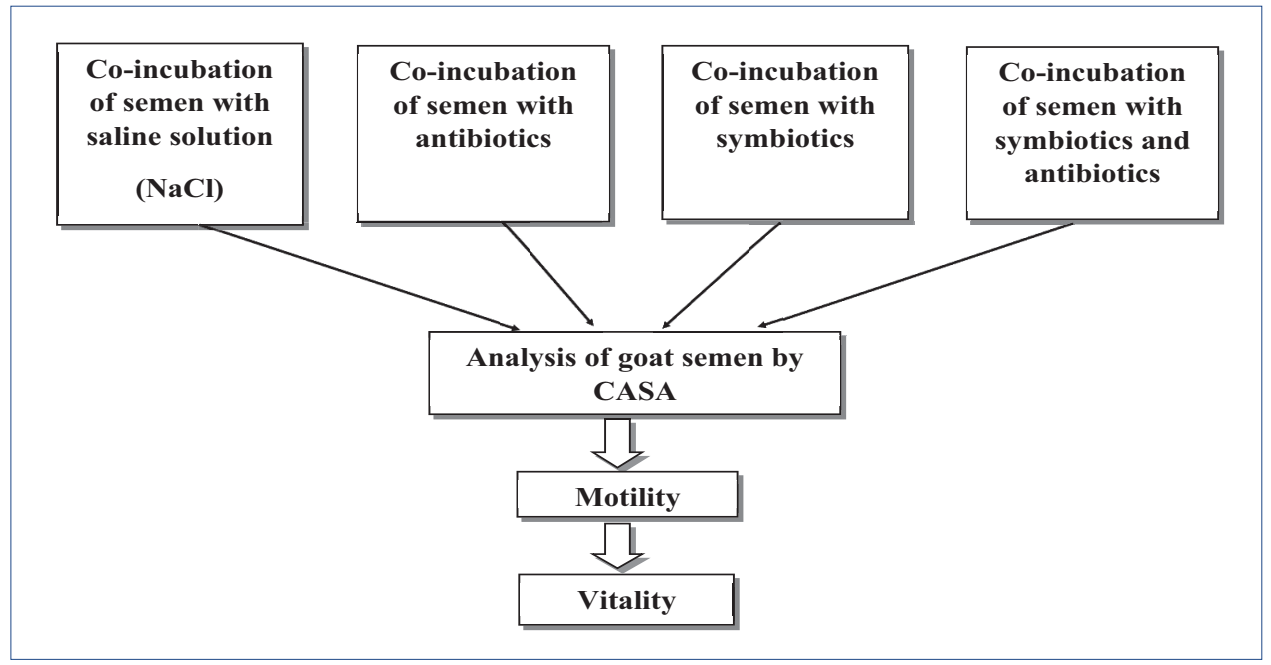

Figure 1. Flowchart of the second part of the study 


\section{Second part}

In this part of the study, we examined the symbiotic effect and the results of coincubation of antibiotics with symbiotic on semen quality (Figure 1).

\section{Protocol for preparing symbiotic and semen solution}

In a labelled Eppendorf flask (sperm + symbiotic), $1 \mathrm{~mL} \mathrm{NaCl}$ (saline solution) was added with $1 \mathrm{~mL}$ symbiotic solution. The solution was mixed using a vortex and placed in a water bath at $37^{\circ} \mathrm{C}$.

\section{Protocol for preparing the sperm solution} co-incubated with the symbiotic and the antibiotics

In a labelled Eppendorf flask (sperm + symbiotic + ATB) containing $1 \mathrm{~mL}$ NACL, we added $1 \mathrm{~mL}$ symbiotic solution, two seed straws, and an antibiotic disc. This was mixed using a vortex and placed in a water bath at $37^{\circ} \mathrm{C}$.

\section{Microscopic analysis}

Microscopic analysis was obtained directly from CASA system which presents objective values of the mobility parameters: curvilinear speed (VCL), average trajectory speed (VTBI), linear speed (VSL), beat cross frequency (BCF) (Figure 2).

\section{Motility}

\section{Control analysis}

The control analysis was performed at $\mathrm{T}_{0}$. Overall spermatozoa movement

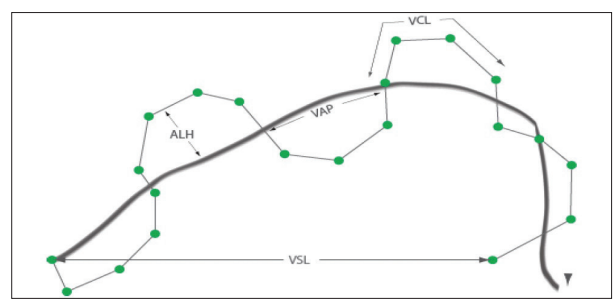

Figure 2. Diagram of the sperm mobility parameters was estimated directly after analysis by observing a drop of sperm under the optical microscope at 10x magnification, Ph1 chamber with green filter, with and a heating plate at $37^{\circ} \mathrm{C}$ to avoid thermal shock or distortion of the results.

\section{Analysis of the antibiotic + semen solution}

For this analysis, the steps were the same as above. However, the results obtained are quite different. The analysis was then reproduced at $T_{1}=30 \mathrm{~min}, \mathrm{~T}_{2}$ $=1 \mathrm{~h}, \mathrm{~T}_{3}=2 \mathrm{~h}$, and $\mathrm{T}_{4}=3 \mathrm{~h}$ for each of the solutions.

\section{Sperm Vitality}

Sperm vitality was ascertained after calculating the number of dead and living (active) sperm in different fields of the optical microscope at 60x magnification, chamber A without filter (Figure 3).
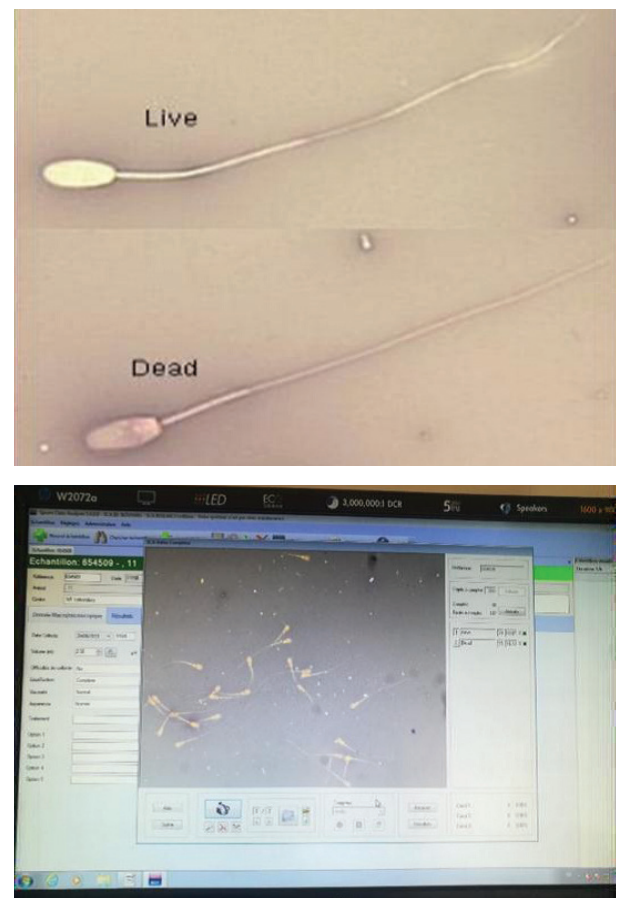

Figure 3. Representation of a colourless live spermatozoa and a pink dead spermatozoa 


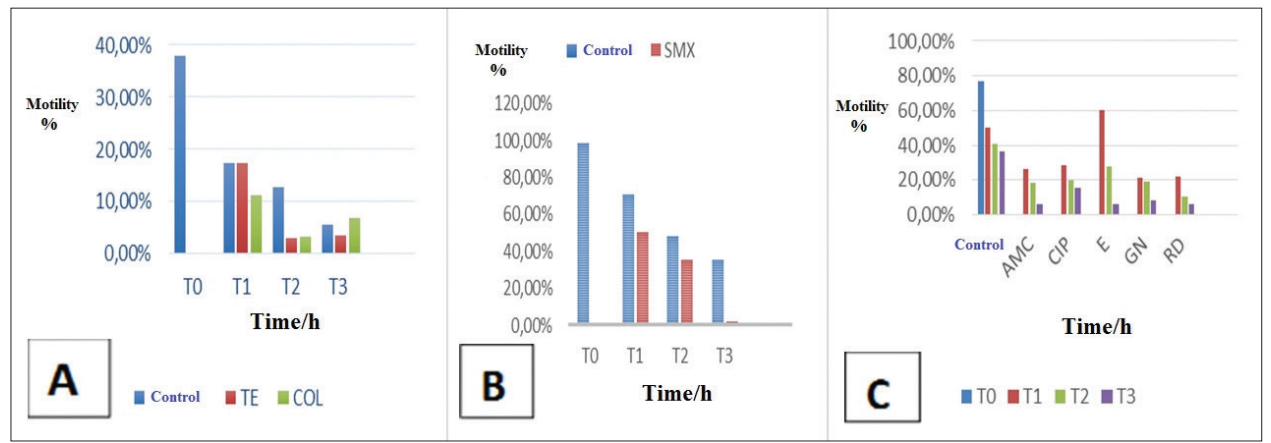

Figure 4. Evolution of motility during the period of co-incubation of spermatozoa with antibiotics (TE, CT, SMX, AMC, CIP, GN, RDJ + the control group

\section{Results}

\section{First part (antibiotics)}

Motility

The results of motility testing are shown in Figure 4.

\section{Figure A}

A progressive decrease was seen in the percentage of motility at $\mathrm{T}_{1}$ and $\mathrm{T}_{2}$ compared to the control group; this shows that the antibiotics (COL and TE) has a detrimental effect on sperm capacities. A slight increase was observed in $\mathrm{T}_{3}$.

\section{Figure B}

A decrease in the percentage of motility was recorded at $\mathrm{T}_{1}, \mathrm{~T}_{2^{\prime}}$ and $\mathrm{T}_{3}$ compared to $\mathrm{T}_{0}$ (control). This is also attributed to the toxic effect of the antibiotic (SMX) on the sperm cell.

\section{Figure $\mathbf{C}$}

The percentage of motility showed a progressive decrease during coincubation of the spermatozoa with (AMC, CIP, GN or RD), except for erythromycin where the value is higher.

\section{Curve speed (VCL)}

The results are shown in Figures 5, 6, and 7:
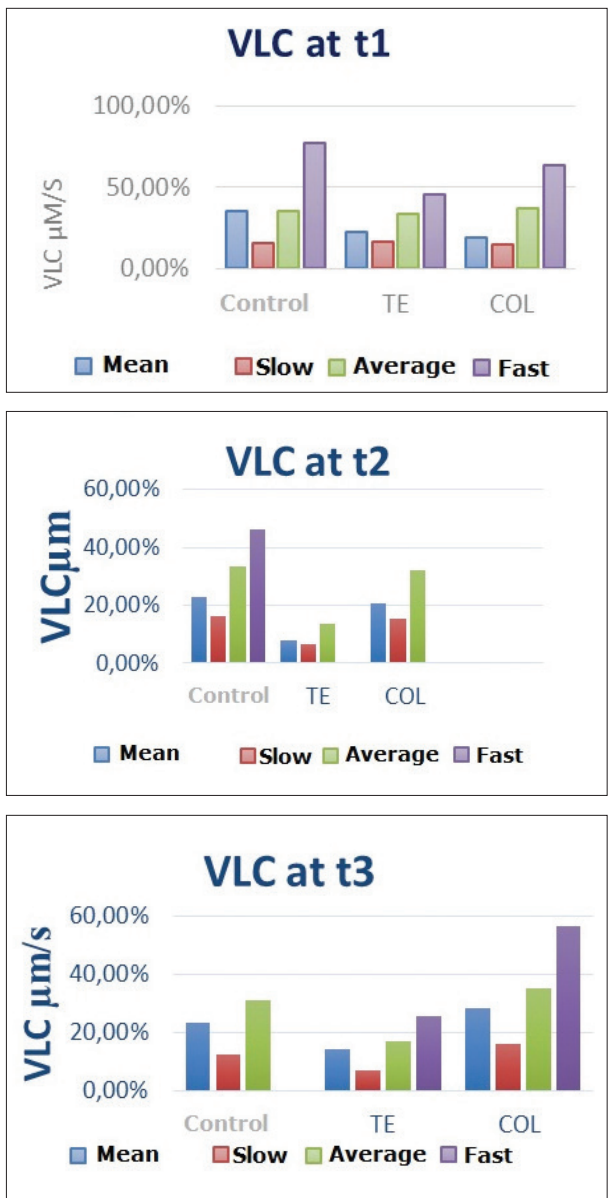

Figure 5. Evolution of VCL during the period of co-incubation of spermatozoa with antibiotics (TE, COL) + the control group 

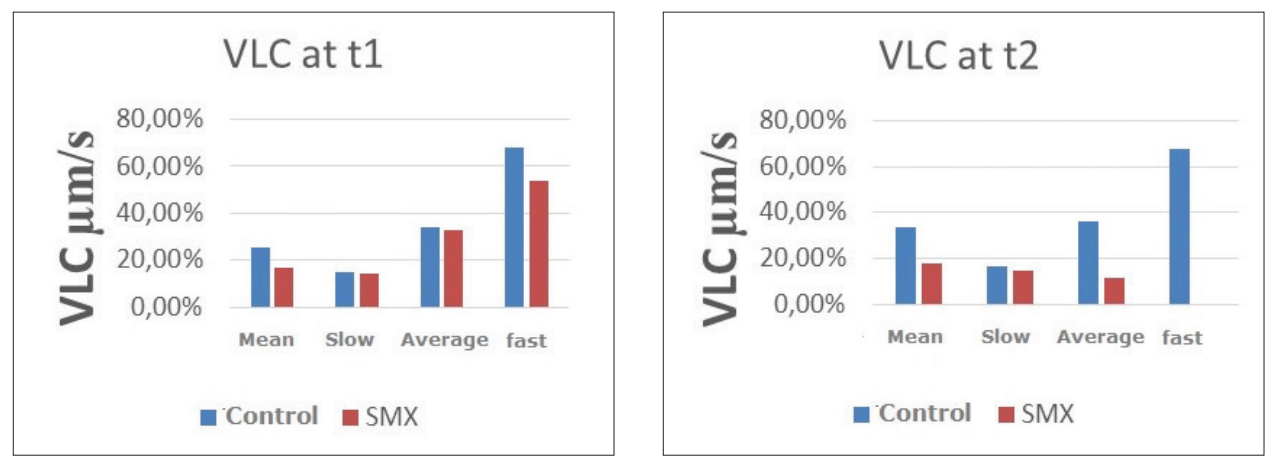

Figure 6. Evolution of VCL during the period of co-incubation of spermatozoa with antibiotics (SMX) + control group
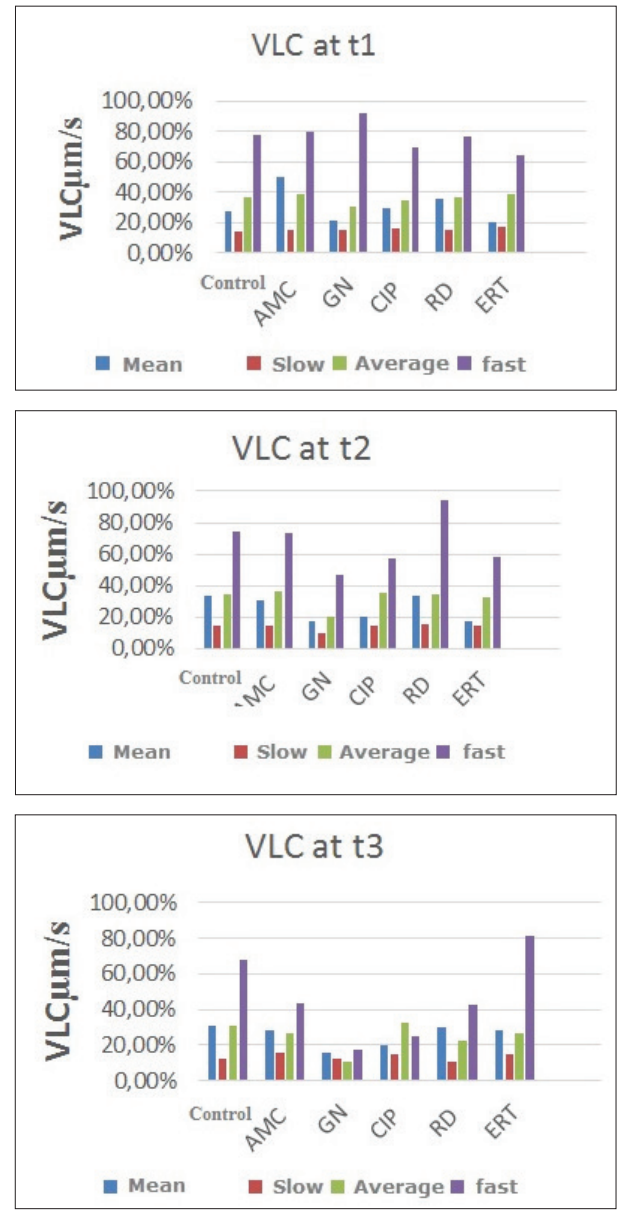

Figure 7. Evolution of the VCL during the period of co-incubation of spermatozoa with antibiotics (AMC, GN, CIP, RD, ERT) + the control group
We noticed a decrease in VLC at $\mathrm{T}_{1}$ and $\mathrm{T}_{2}$ during co-incubation of sperm with COLs and TEs, and an increase in VLC at $\mathrm{T}_{3}$ compared to the control VLC (Figure 3). We recorded a decrease in VLC at $\mathrm{T}_{1}$ and $\mathrm{T}_{2}$ with SMX compared to the control VLC (Figure 4).

Regarding the results illustrated in Figure 7:

At $\mathrm{T}_{1}$ : A decrease in VLC was observed during co-incubation with CIP and ERT and a slight decrease with RD compared to the control. On the other hand, an increase was recorded during the period of co-incubation with GN and AMC.

At T2: A decrease in VLC was observed with AMC, GN, CIP, ERT, CIP and a significant increase in VLC with RD.

At T3: A decrease in sperm VLC was also observed during co-incubation with AMC, GN, CIP, RD, and a marked increase with ERT.

\section{Linear Speed (VSL)}

The values of VSL of semen of the control group and of each antibiotic are represented at the three test times in Figures 8, 9 and 10.

Regarding the results illustrated in Figure 8:

At $\mathrm{T}_{1}$ and $\mathrm{T}_{3}$ : We noted a decrease in VSL compared to the control group except for AMC, where the VSL is increased. 

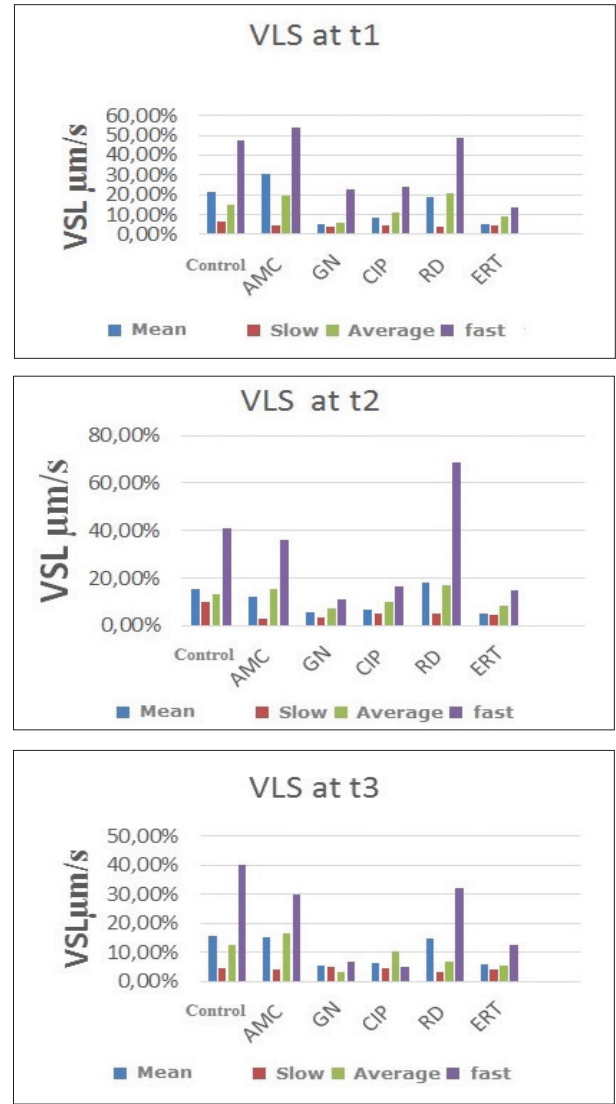

Figure 8. Evolution of the VSL of spermatozoa co-incubated with antibiotics (AMC, GN, CIP, RD, ERT) as a function of time + control group

At $\mathrm{T}_{2}$ : There is a significant increase in the VSL of the spermatozoa co-incubated with the ED.

Regarding the results illustrated in Figure 9:

At $\mathrm{T}_{1}$ : A significant decrease in VSL was recorded compared to the control group.

At $\mathrm{T}_{2}$ : At this stage the VSL is stationary.

At $\mathrm{T}_{3}$ : We noticed a resumption of the VSL again, especially of semen coincubated with COL and TE.

The results illustrated in Figure 8 show a decrease in VSL at $\mathrm{T}_{2}$ and $\mathrm{T}_{3}$ with SMX compared to the control group.

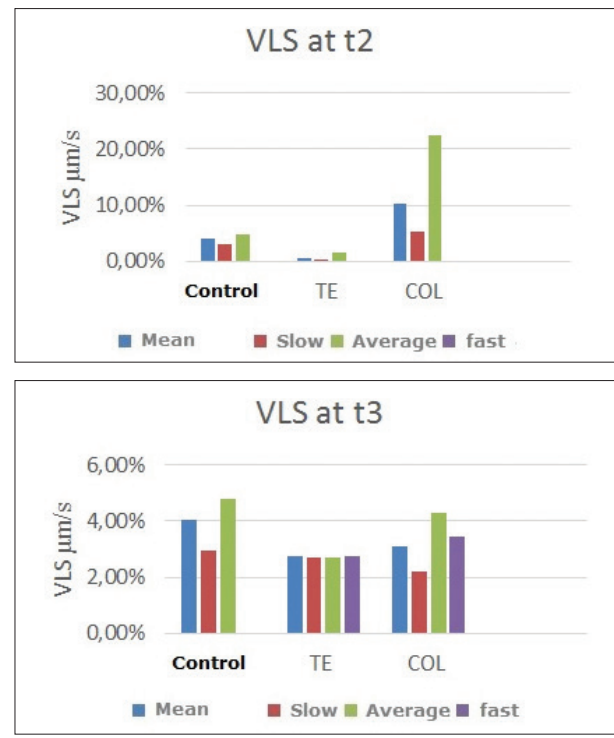

Figure 9. Evolution of the VSL of the spermatozoa co-incubated with the antibiotics (TE, COL) as a function of time + control group
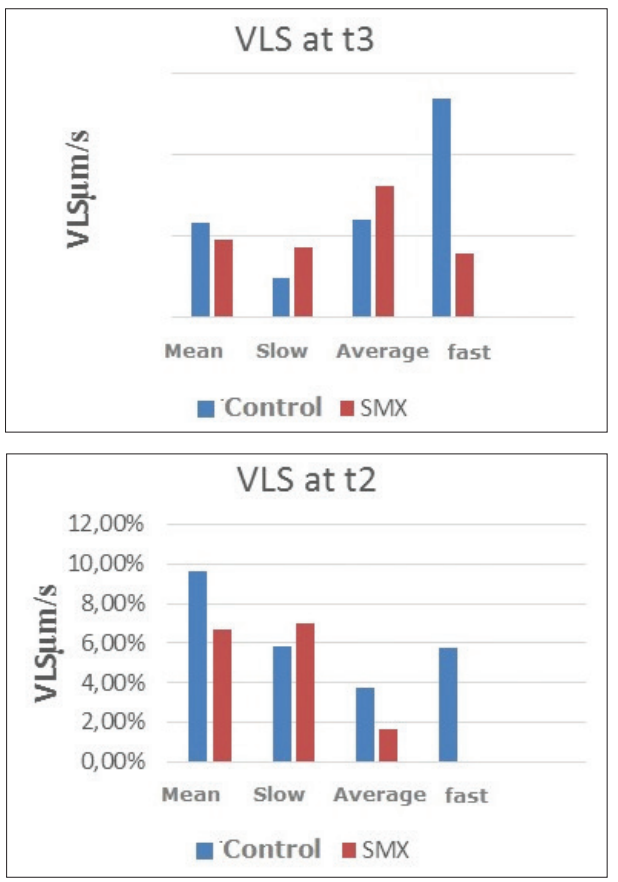

Figure 10. Evolution of the VSL of spermatozoa co-incubated with antibiotic (SMX) as a function of time + control group 


\section{Part two}

The results of this part are illustrated by the following tables and figures:

From Table 2 and Figure 11, it can be seen that vitality and motility of spermatozoa co-incubated with the symbiotic was better compared to the control.

Motility and vitality were also improved when the sperm were co- incubated together with the symbiotic and colistin (Table 3 and Figure 12).

The evolution of motility and vitality over time was better than when the semen was co-incubated solely with the symbiotic. However, the combination of the symbiotic with cotrimoxazole showed no benefits (Table 4, Figure 13).

Table 2. Motility and vitality of the symbiotic and the control

\begin{tabular}{|c|c|c|c|c|}
\hline Sample & \multicolumn{2}{|c|}{ Control group } & \multicolumn{2}{|c|}{ Symbiotic } \\
\hline Time & Vitality & Motility & Vitality & Motility \\
\hline $\mathrm{T}_{0}$ & $69 \%$ & $74 \%$ & $69 \%$ & $74 \%$ \\
\hline $\mathrm{T}_{1}$ & $60 \%$ & $50 \%$ & $64 \%$ & $62 \%$ \\
\hline $\mathrm{T}_{2}$ & $50 \%$ & $42 \%$ & $58 \%$ & $48 \%$ \\
\hline $\mathrm{T}_{3}$ & $44 \%$ & $30 \%$ & $50 \%$ & $38 \%$ \\
\hline $\mathrm{T}_{4}$ & $32 \%$ & $25 \%$ & $38 \%$ & $30 \%$ \\
\hline
\end{tabular}
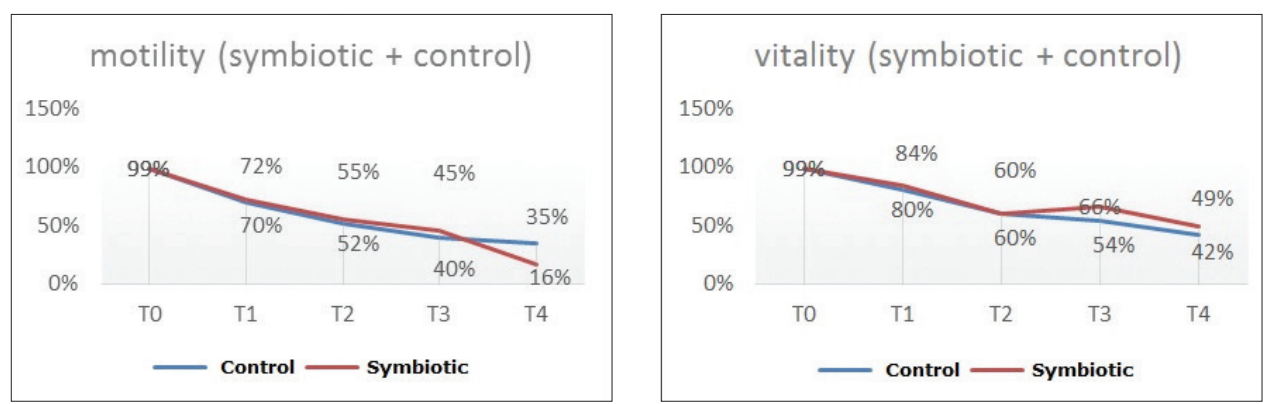

Figure 11. Evolution of the motility and vitality of semen co-incubated with the symbiotic, and the control

Table 3. Evolution of the motility and vitality with the symbiotic and colistin.

\begin{tabular}{|c|c|c|c|c|c|c|}
\hline Sample & \multicolumn{2}{|c|}{ Symbiotic } & \multicolumn{2}{c|}{ Colistin } & \multicolumn{2}{c|}{ Symbiotic + Colistin } \\
\hline Time & vitality & motility & vitality & motility & vitality & motility \\
\hline T0 & $99 \%$ & $99 \%$ & $99 \%$ & $99 \%$ & $98 \%$ & $99 \%$ \\
\hline T1 & $84 \%$ & $72 \%$ & $59 \%$ & $30 \%$ & $80 \%$ & $77 \%$ \\
\hline T2 & $60 \%$ & $55 \%$ & $16 \%$ & $8 \%$ & $70 \%$ & $64 \%$ \\
\hline T3 & $66 \%$ & $45 \%$ & $12 \%$ & $6 \%$ & $77 \%$ & $50 \%$ \\
\hline T4 & $49 \%$ & $16 \%$ & $9 \%$ & $5 \%$ & $40 \%$ & $19 \%$ \\
\hline
\end{tabular}



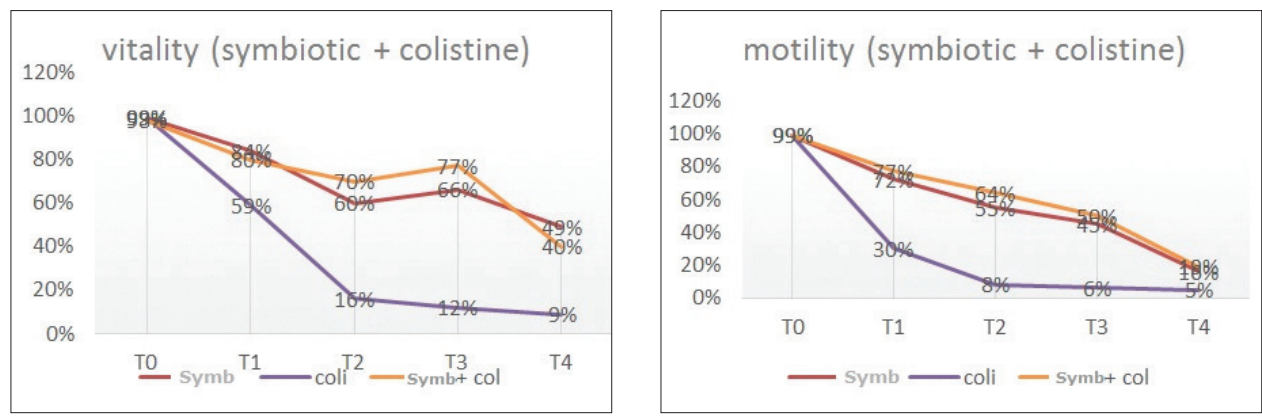

Figure 12. Evolution of the motility and vitality of semen co-incubated with the symbiotic and colistin

Table 4. Evolution of the motility and vitality of semen co-incubated with the symbiotic and cotrimoxazole (Cot).

\begin{tabular}{|c|c|c|c|}
\hline Sample & Symbiotic & Cot & Symbiotic + Cot \\
\hline Time & Motility & Motility & Motility \\
\hline T0 & $99 \%$ & $99 \%$ & $99 \%$ \\
\hline T1 & $72 \%$ & $40 \%$ & $43 \%$ \\
\hline T2 & $55 \%$ & $36 \%$ & $40 \%$ \\
\hline T3 & $45 \%$ & $25 \%$ & $36 \%$ \\
\hline T4 & $16 \%$ & $13 \%$ & $14 \%$ \\
\hline
\end{tabular}
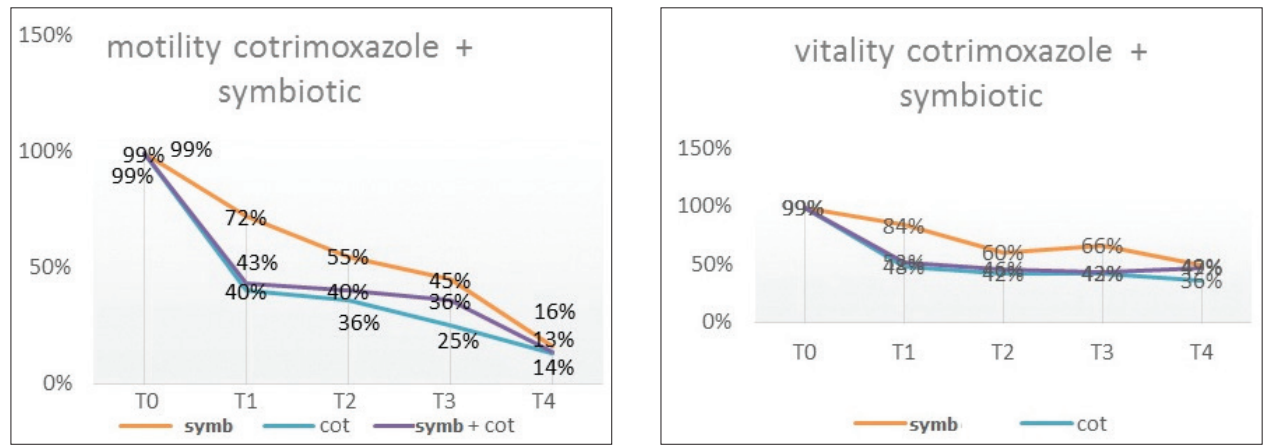

Figure 13. Evolution of the motility and vitality semen co-incubated with the symbiotic and cotrimoxazole

\section{Discussion}

Subclinical endometritis is treated with antibiotics using two strategies: treat and inseminate at the same time; or treat and let the female rest with insemination taking place after 21 days (Kasimanickam et al., 2005; Leblanc, 2009). Previous studies in vivo and in vitro showed that antibiotics negatively affect the sperm cell, and so AI is known to fail if insemination is performed immediately following treatment. Overall, the results presented here demonstrate that the treatment of spermatozoa with antibiotics induced an altering effect on sperm mobility. 
The deleterious effect of tetracycline on sperm mobility is well documented in the literature. This antibiotic is responsible for inhibiting the capacitation of sperm and the acrosome reaction. Indeed, its ability to chelate calcium can be very relevant, as calcium is not only involved in the initiation of sperm movement in mature mammals, but it is also crucial for hyperactivation (Yanagamachi, 1994). In addition, this drug is a fluorophore: it binds avidly to human sperm. This connection may actually present a physical obstruction to motility (Ericsson and Baker, 1967). Other studies have also shown that the therapeutic dose of tetracycline induces a toxic sperm and testicular effect in male rats by induction of oxidative stress (Farombi et al., 2008).

Our in vitro exposure of spermatozoa to gentamycin MIC induced a significant alteration in their mobility. Studies by Aral et al. (2008) in vivo showed the same results. Co-incubation of sperm with erythromycin, ciprofloxacin and sulfamethoxazole demonstrated an alteration of all sperm motility parameters; the same results were noticed for rifampicin and colistin. However, studies carried out by Hargreaves et al. (1998) have shown a significant improvement in sperm mobility. Studies have been reported in the literature on sperm agglutination. This phenomenon was observed during co-incubation with rifampicin and colistin. The effects of these two antibiotics have been studied by several authors; they demonstrated that the agglutination of spermatozoa can lead to a decrease in mobility and poor penetration of the cervical mucus, influence selection in the genital tract, impede capacitation and finally, and inhibit fertilization of the ovum.

Co-incubation with amoxicillin + clavulanic acid induced alteration, though there are no literature data on this combination. The study by Hargreaves et al. (1998) on amoxicillin alone showed no significant effect on mobility.

The symbiotics co-incubated with semen showed better results than those of the control, and also compared to those obtained with the antibiotics. In fact, the molecule used in our study is an association between a symbiotic, prebiotic and yeasts, which could explain its beneficial effects.

In a previous study, Barbonetti et al. (2011), found that a combination of three selected strains of Lactobacilli (Lactobacillus brevis, L. salivarius, and L. plantarum), whose efficacy in the treatment of bacterial vaginosis in the form of vaginal tablets has been recently reported, was effective in preventing lipid peroxidation of sperm induced in vitro by a ferrous ion promoter, thus preserving sperm motility and viability. This finding suggests that the vaginal application of symbiotic Lactobacilli could protect human sperm from radical oxygen species in the presence of vaginal disorders, thereby improving the fertilization potential of the female host.

According to Maretti and Cavallini (2017), sperm count was improved after treating oligo-astheno-teratospermia. According to Valcarce et al. (2017), sperm motility was significantly improved after treatment with two strains of symbiotics in males with astheno-spermia. The results reported in this study provide preliminary evidence for the possibility of administering symbiotics to improve motility.

\section{Conclusion}

The present study was aimed at studying the impact of antibiotics and symbiotics on sperm mobility and vitality parameters in vitro. Antibiotics cause damage to the sperm cell during AI, and during treatments performed on male breeding animals of all species, including humans. The facts were confirmed by our 
results obtained by the CASA system; we have demonstrated an alteration of sperm co-incubated with antibiotics. In addition, symbiotics showed a beneficial effect, on both motility and vitality. Overall, the results obtained under our experimental conditions are promising. A symbiotic and antibiotic combination remains to be confirmed, with the ultimate aim of ceasing the indiscriminate use of antibiotics.

\section{References}

1. AHMADI, M. R., S. NAZIFI and H. R. GHAISARI (2006): Comparative cervical cytology and conception rate in postpartum dairy cows. Vet. arhiv 76, 323-332.

2. ARAL, F., F. KARAKAL and F. BABA (2008): The effect of enrofloxacin on sperm quality in male mice. Res. Vet. Sci. 84, 95-99. 10.1016/j.rvsc.2007.04.007

3. ASADPOUR, R., L. FEYZI, R. JAFARI-JOOZANI, H. HAMALI, A. HAJIBEMANI and M. FIROUZAMANDI (2020): The relationship between polymorphism of the CXCR1 gene and the risk of endometritis in Holstein dairy cows. Vet. arhiv 90, 557-563. 10.24099/vet. arhiv. 0807

4. BARBONETTI, A., B. CINQUE, M. R. C. VASSALLO, S. MINEO, S. FRANCAVILLA, M. G. CIFONE and F. FRANCAVILLA (2011): Effect of vaginal probiotic lactobacilli on in vitro-induced sperm lipid peroxidation and its impact on sperm motility and viability. Fertil. Steril. 95, 8. 10.1016/j. fertnstert.2011.03.066

5. ĐURIČIĆ, D., M. LIPAR and M. SAMARDŽIJA (2014): Ozone treatment of metritis and endometritis in Holstein cows. Vet. arhiv 84, 103-110.

6. ĐURIČIĆ, D., P. KOČILA, G. GREGURIĆ-GRAČNER, F. MARKOVIĆ, M. HORVAT and M. SAMARDŽIJA (2013): Bakteriologische Untersuchungen von Uterusabstrichen bei Kühen mit dem Repeat breeding Syndrom. Tierärztl. Umsch. 68, 262-265.

7. ĐURIČIĆ, D., H. VALPOTIĆ and M. SAMARDŽIJA (2015): Prophylaxis and therapeutic potential of ozone in buiatrics : Current knowledge. Anim. Reprod. Sci. 159, 1-7. 10.1016/j. anireprosci.2015.05.017

8. ERICSSON, R. J. and V. F. BAKER (1967): Binding of Tetracycline to Mammalian Spermatozoa. Nature 214, 403-404. 10.1038/214403a0

9. FAROMBI, E. O., M. C. UGWUEZUNMBA, T. T. EZENWADU, M. O. OYEYEMI and M. EKOR (2008): Tetracycline-induced reproductive toxicity in male rats: effects of vitamin $\mathrm{C}$ and $\mathrm{N}$-acetylcysteine. Exp. Toxicol. Pathol. 60, 77-85. 10.1016/j.etp.2008.02.002

10. HARGREAVES, C. A., S. ROGERS, F. HILLS, F. RAHMAN, R. J. HOWELL, S. T. HOMA (1998): Effets du cotrimoxazole, de l'érythromycine, de l'amoxycilline, de la tétracycline et de la chloroquine sur la fonction du sperme in vitro. Hum. Reprod. 13, 1878-1886.

11. KASIMANICKAM, R., T. F. DUFFIELD, R. A. FOSTER, C. J. GARTLEY, K. E. LESLIE, J. S. WALTON et al. (2005): The effect of a single administration of cephapirin or cloprostenol on the reproductive performance of dairy cows with subclinical endometritis. Theriogenology 63, 818830. 10.1016/j.theriogenology.2004.05.002

12. LEBLANC, M. M. (2009): The current status of antibiotic use in equine reproduction. Equine Vet. Educ. 21, 3, 156167.

13. MARETTI, C. and G. CAVALLINI(2017): The association of probiotic with a prebiotic (Flortec, Bracco) to improve the quality/quantity of spermatozoa in infertile patients with idiopathic oligoasthenoteratospermia: a pilot study. Andrology 5, 439-444. 10.1111/andr.12336

14. ORUC, E., Y.S. SAGLAM, B. POLAT, M. CENGIZ, A. COLAK, S. ALTUN, O. CANNAZIK and K.A. T. KAPAKIN (2015): The evaluation of endometrial cytology in cows with acute and he evaluation of endometrial cytology in cows with acute and chronic endometritis Vet. arhiv 85, 131-140.

15. SAMARDŽIJA, M., R. TURK, P. SOBIECH, H. VALPOTIĆ, I. HARAPIN, D. GRAČNER and D. ĐURIČIĆ (2017): Intrauterine ozone treatment of puerperal disorders in domestic ruminants: a review. Vet. arhiv 87, 363-375. 10.24099/vet. arhiv.160119a

16. SZENCI, O., Z. SZELÉNYI, L. LÉNÁRT, D. BUJÁK, L. KOVÁCS, L. F. KÉZÉR, B. HAN and A. HORVÁTH (2018): Importance of monitoring the peripartal period to increase reproductive performance in dairy cattle. Vet. stn. 49, 297-307.

17. VALCARCE, D., S. GENOVES, M. RIESCO, P. MARTORELL, M. HERRAEZ, D. RAMON and V. ROBLES (2017): Probiotic administration improves sperm quality in asthenozoospermic human donors. Benif. Microbes 8, 2. 10.3920/BM2016.0122

18. YANAGAMACHI, R. (1994): Mammalian fertilization. In: Knobil, E., Neill, J. D. (eds), The Physiology of Reproduction, $2^{\text {nd }}$ edn. Raven Press, New York, pp. 189-317.

19. ŽURA ŽAJA, I., M. SAMARDŽIJA, S. VINCE, I. MAJIĆBALIĆ, D. ĐURIČIĆ and S. MILINKOVIĆTUR (2016a): Antioxidant system parameters in boar spermatozoa of different morphology and motility. Vet. arhiv 86, 655-666.

20. ŽURA ŽAJA, I., M. SAMARDŽIJA, S. VINCE, M. VILIĆ, I. MAJIĆ-BALIĆ, D. ĐURIČIĆ and S. MILINKOVIĆ-TUR (2016b): Differences in seminal plasma and spermatozoa antioxidative systems and seminal plasma lipid and protein levels among boar breeds and hybrid genetic traits. Anim. Reprod. Sci. 170, 75-82. 10.1016/j. anireprosci.2016.04.006

21. ŽURAŽAJA,I.,A.SLUGANOVIĆ, M.SAMARDŽIJA, S. MILINKOVIĆ-TUR, T. DOBRANIĆ, S. STRELEC, D. ĐURIČIĆ, H. VALPOTIĆ and S. VINCE (2019a): The effects of oxidative stress on the male reproductive 
system and mechanisms of antioxidant protection. Vet. stn. 50, 43-54. (In Croatian).

22. ŽURA ŽAJA, I., I. ŠVUB, S. MILINKOVIĆ-TUR, S. VINCE, H. VALPOTIĆ, D. ĐURIČIĆ, S. ČIPČIĆ and M. SAMARDŽIJA (2019b): Biochemical parameters of seminal plasma in domestic animals and humans. Vet. stn. 50, 223-237. (In Croatian).

\section{Studija učinka antibiotika i simbiotika na kvalitetu sperme putem sustava računalno potpomognute analize sperme}

Ahmed El Bachir BOUCHICHA, Ammar KALEM, Laboratory of Biotechnologies related to animal reproduction (LBRA), Institute of Veterinary Sciences, Saad Dahleb University, Blida, Algeria, Institute of Sciences and Technology, Tissemsilt University; Nora MIMOUNE, Laboratory of Biorechnologies related to animal reproduction (LBRA), Institute of Veterinary Sciences, Saad Dahleb University, Blida, Algeria, National High School of Veterinary Medicine, Animal Health and Productions Laboratory, El-Alia, Algiers, Algeria; Sohaib DJOUADI, Faculty of Nature \& Life Sciences, Farm Animal Reproduction Laboratory, University of Tiaret, Algeria; Djamel KHELEF, National High School of Veterinary Medicine, Animal Health and Productions Laboratory, El-Alia, Algiers, Algeria; Rachid KAIDI, Laboratory of Biorechnologies related to animal reproduction (LBRA), Institute of Veterinary Sciences, Saad Dahleb University, Blida, Algeria

Cilj je ovoga rada bio proučiti in vitro kvalitetu sperme nakon dodavanja antibiotika i simbiotika te procijeniti terapiju danu nedugo prije osjemenjivanja da bi se smanjio broj neuspješnosti umjetnih osjemenjivanja (AI) u koza. Naša eksperimentalna studija provedena je u Laboratoriju za asistiranu reprodukciju životinja (Blida, Alžir). Analiza sjemena provedena je sustavom računalno potpomognute analize sperme (CASA). Za prvi eksperimentalni pristup rabili smo antibiotike koji se najčešće daju u veterini za liječenje subkliničkog endometritisa (SCE), a proučeno je ukupno osam antibiotika. Svaki ispitani antibiotik bio je koinkubiran sa zamrznutim sjemenom koza iz Centra za umjetno osjemenjivanje i genetsko poboljšanje (CNIAAG). Za drugi pristup koinkubirali smo spermu sa simbiotikom (Symbiovéba). $\mathrm{Na}$ kraju smo izabrali dva antibiotika među onima rabljenima - kolistin i kotrimoksazol.
Da bismo pokušali pronaći moguću kombinaciju antibiotika sa simbioticima u liječenju i prevenciji infekcije maternice (široki spektar sinergizirane aktivnosti) koinkubirali smo ih sa simbiotikom i sjemenom. Pokazalo se da antibiotici imaju negativan učinak na spermije jer su prouzročili smanjenje njihove pokretljivosti. Prosječna izračunata vrijednost na svim antibioticima bila je $18 \%$ (početna pokretljivost kontrolne skupine bila je $78 \%$ ) te promjena linearne brzine koja bi imala negativan učinak na oplodnju, dok su simbiotici su imali blagotvorni učinak na pokretljivost i vitalnost sperme. Kombinacija simbiotika i kolistina bila je vrlo obećavajuća što znači, da je uporaba simbiotika u liječenju subkliničkog endometritisa (SCE) u vrijeme umjetnog osjemenjivanja koza korisna, ali ju je potrebno i dalje pratiti i istraživati.

Ključne riječi: sperma, antibiotik, simbiotik, CASA, sjeme, subklinički endometritis 